\title{
ОПТИМІЗАЦІЯ ОПОДАТКУВАННЯ ЯК ЕФЕКТИВНИЙ ІНСТРУМЕНТ ПІДВИЩЕННЯ РІВНЯ ЕКОНОМІЧНОЇ БЕЗПЕКИ ПІДПРИЕМСТВА
}

Онісіфорова В.Ю., канд. екон. наук, доцент

Харківський національний автомобільно-дорожсній університет

Сідельнікова В.К., канд. пед. наук, доцент

Харківський національний педагогічний університет імені Г.С. Сковороди

Постановка проблеми. Сучасне вітчизняне підприємство в своїй діяльності щоденно має справу з великою кількістю зовнішніх і внутрішніх загроз його стабільному становищу на ринку та економічній безпеці. Ефективне реагування на весь перелік загроз і використання ефективних інструментів підвищення рівня економічної безпеки стають на сьогодні нагальною щоденною потребою для підприємства, яке має намір зберегти достатній рівень економічної ефективності та позиції на ринку.

Аналіз останніх досліджень та публікацій. Проблемам управління економічною безпекою підприємства приділяє увагу у свої роботах велика кількість науковців. Це пояснюється актуальністю теми не лише на рівні науки, але й на рівні практикуючих економістів, керівників і власників підприємств. Значний ряд авторів зосереджують свою увагу на виділенні складових економічної безпеки підприємства, формуванні ефективних підходів до об'єктивного оцінювання іiі рівня, формують переліки загроз економічній безпеці підприємства та пропонують заходи щодо реагування на них [1-7]. Однак на сьогодні все більша кількість дослідників починає конкретизувати проблему залежно від масштабів діяльності підприємства, особливостей виду діяльності, досліджують проблему управління економічною безпекою за галузевою ознакою та аналізують принципові відмінності управління нею для малих і середніх підприємств [8].

Невирішені складові загальної проблеми. Не зважаючи на значну кількість досліджень, недостатньо уваги приділено заходам підвищення рівня економічної безпеки (відповідно до іiї функціональних складових) підприємств, які за обсягами обороту та видом діяльності мають можливість обирати між роботою за спрощеною системою оподаткування та за загальною системою оподаткування. Недостатньо проаналізовано вплив цього аспекту на загальну ефективність діяльності підприємства в розрізі конкретних іiі функціональних складових.

Формулювання цілей статті. Метою статті $є$ дослідження можливості оптимізації оподаткування діяльності підприємства за рахунок обгрунтованого вибору системи оподаткування як інструмента підвищення рівня економічної безпеки підприємства.

Виклад основного матеріалу дослідження. Досліджуючи проблему впливу вибору системи оподаткування діяльності підприємства на рівень його 
економічної безпеки, необхідно першочергово визначити, що саме представляє собою такий стан підприємства, та проаналізувати чи існують відмінності для підприємств у процесі досягнення такого стану відповідно до розміру підприємства, яким чином проявляють себе загрози економічній безпеці саме в розрізі діяльності малих і середніх підприємств.

Відповідно до погляду науковців, які приділяють увагу дослідженню проблеми економічної безпеки підприємства, стан економічної безпеки - це така ситуація на підприємстві, при якій воно знаходиться в стані захищеності від негативних впливів та змін, або в стані, в якому ймовірність небажаних змін параметрів діяльності підприємства знаходиться у припустимих власником межах [5]. Аналізуючи таке визначення стану економічної безпеки підприємства, можна зазначити, що вибір неефективної системи оподаткування діяльності підприємства може привести до негативних змін і становити загрозу показникам загальної ефективності підприємства. Тобто означену проблему можна розглядати в розрізі управління економічною безпекою.

Розглянемо наступний аспект процесу управління економічною безпекою підприємства, а саме визначимо ті їі складові, які можуть зазнати негативного впливу у разі використання підприємством неефективної системи оподаткування. В дослідженнях найбільш розповсюдженими на сьогодні є такі погляди та підходи до класифікації складових економічної безпеки підприємства: системний, ресурсний, функціональний та за видом діяльності $[1 ; 5 ; 7]$.

У попередньому дослідженні [9] було обгрунтовано критерій вибору системи оподаткування, яким визначено рівень прибутковості, тобто у разі обрання невідповідної до останнього системи підприємство штучно завищує рівень податків, а відповідно, це спричиняє зниження показників фінансового стану. Розглянемо, відповідно до цього бачення, вплив такого неефективного вибору на показники економічної безпеки за складовими в межах кожного 3 підходів до класифікації складових економічної безпеки.

Відповідно до системного підходу прийнято виділяти наступні складові економічної безпеки підприємства. Ресурсна складова передбачає всі загрози та чинники, які мають вплив на матеріальне забезпечення підприємства основними видами ресурсів. У межах такої складової можна стверджувати, що безпосереднього впливу неефективний вибір системи оподаткування на неї не має, однак збільшений розмір податків зменшує кошти підприємства, а отже, спричиняє зменшення обсягів оборотних коштів, що, в свою чергу, негативним чином впливає на ресурсне забезпечення. Технологічна складова зосереджує всі загрози технічній стороні виробничого процесу, основним засобам, технологічному рівню виробництва. Вплив досліджуваної проблеми на означену складову є дуже опосередкованим: на наш погляд, завищений рівень податків для малих і середніх підприємств не має в загальному випадку спричинити істотного впливу на процеси оновлення основних виробничих засобів. Соціальна складова розглядає загрози всім аспектам діяльності, пов'язаним із персоналом. На наш погляд, неефективний вибір системи 
оподаткування результатів діяльності підприємства загрози цій складовій економічної безпеки не становить. Фінансова складова уособлює всі аспекти, які формують фінансовий стан, визначають рівень прибутковості, ліквідність і платоспроможність підприємства. На наш погляд, це головна складова, яка зазнає безпосереднього негативного впливу 3 боку такої загрози, як неефективна система оподаткування.

Відповідно до ресурсного підходу прийнято виділяти: безпеку техніки та обладнання; безпеку персоналу; безпеку інформації та технологій; безпеку прав; безпеку капіталу. Зміст кожної зі складових випливає з самої назви. Аналізуючи їх за змістом, можна стверджувати, що безпосереднього впливу від завищеного рівня сплачених податків, зрозуміло, зазнає складова безпеки капіталу, яка стосується безпеки фінансових ресурсів підприємства.

Найбільш розповсюдженим підходом при класифікації складових економічної безпеки підприємства $\epsilon$ функціональний, відповідно до якого виділяють наступні їх види. Техніко-технологічна складова стосується технологічного рівня виробництва, виробничого обладнання, інтелектуальних ресурсів у невиробничій сфері. В межах цієї складової суттєвого впливу досліджувана загроза, на наш погляд, не має. Інтелектуально-кадрова складова містить всі аспекти, що стосуються кадрового складу підприємства та інтелектуально-інноваційних якостей працівників. Можливим аспектом впливу на цю складову може бути переспрямування коштів підприємства від заробітної плати в напрямку сплати збільшених податків. Політико-правова складова головним чином стосується правового забезпечення роботи підприємства, тому досліджувану загрозу можна не вважати небезпечною щодо цієї складової. Фінансова складова визначається спрямованістю комерційного підприємства на максимізацію прибутку, а саме воно зазнає безпосереднього негативного впливу при сплаті завищеного рівня податків, тобто, можна стверджувати, що досліджувана загроза є небезпечною для цієї складової. Інформаційна складова стосується інформаційного забезпечення діяльності підприємства та процесу прийняття управлінських рішень. Досліджувану загрозу, на наш погляд, як істотно небезпечну в межах цієї складової можна не розглядати. Екологічна складова стосується екологічних впливів діяльності підприємства. В межах нашого дослідження також не зазнає істотного впливу від аналізованої загрози. Силова складова стосується, головним чином, збереження майна, фізичної захищеності персоналу, отже також не піддається впливу досліджуваної загрози.

Ще одним розповсюдженим підходом до класифікації складових економічної безпеки є класифікація за видом діяльності. Виробнича безпека уособлює всі аспекти, що формують процес виробництва продукції на підприємстві. Складова поєднує в собі технічну, матеріальну, кадрову безпеку, безпеку збуту, тобто, враховуючи негативний вплив досліджуваної загрози на стан оборотних коштів, можна стверджувати, що ця складова знаходиться під негативним впливом від загрози обрання неефективної системи оподаткування. Фінансова безпека формується як безпека фінансового стану, кредитна безпека 
та безпека фінансових операцій. Безперечно, досліджувана загроза $\epsilon$ небезпечною в розрізі даної складової. Інвестиційна безпека передбачає безпеку фінансових і реальних інвестицій підприємства. Така складова має дуже опосередкований неістотний для врахування вплив від досліджуваної загрози.

Висновки 3 проведеного дослідження. Проведене дослідження дозволяє стверджувати, що загроза вибору неефективної системи оподаткування діяльності підприємства є дійсно істотною та спрямовує свій вплив на певні складові економічної безпеки підприємства в межах кожного 3 найбільш розповсюджених на сьогодні поглядів на їх класифікацію і, головним чином, впливає на фінансові аспекти діяльності підприємства, а також спричиняє негативний вплив на його оборотні кошти.

\section{Перелік посилань}

1. Андрієнко В. М. Сучасні підходи до забезпечення економічної безпеки будівельних підприємств. Будівельне виробнищтво. 2013. № 55. С. 1422.

2. Близнюк А. О. Аналіз стану системи управління економічною безпекою підприємств автотранспортної галузі. Проблеми $i$ перспективи розвитку підприсмництва : зб. наук. пр. Харк. нац. автомоб-дор. ун-т. Х.: ХНАДУ. 2015. № 3(10). Т. 2. С. 121-125.

3. Воронков О. О., Дяченко К. С. Концептуальні засади дослідження економічної безпеки будівельних підприємств. Вісник Житомирського державного технологічного університету. Серія: Економічні науки. 2017. № 4. C. $117-124$.

4. Дмитренко В. І. Методичний підхід до оцінювання стану системи економічної безпеки будівельних підприємств під впливом державного регулювання. Вісник Черкаського університету. 2015. № 33(366). Серія «Економічні науки». С. 37-42.

5. Дмитрієв I. А., Близнюк А. О., Онісіфорова В. Ю. Управління економічною безпекою автотранспортного підприємства: монографія. Харків, 2014. $216 \mathrm{c}$.

6. Фісуненко П. А., Лаже М. В. Особливості забезпечення економічної безпеки будівельних підприємств. Шляхи підвищення ефективності будівниитва в умовах формування ринкових відносин. 2015. Вип. 33. С. 156-164.

7. Черкасова С. О. Формування організаційно-економічного механізму управління процесом зміцнення економічної безпеки промислових підприємств. Економіка і реалії часу. 2013. № 2. С. 22-27.

8. Дмитрієв І. А., Майборода Ю. В. Соціально-економічна сутність малого підприємництва, проблеми його розвитку в Україні. Проблеми $i$ перспективи розвитку підприємництва. 2012. № 1. С. 35-38.

9. Онісіфорова В. Ю., Сідельнікова В. К. Спрощена система оподаткування: сучасний стан, переваги, недоліки та перспективи. Проблеми $i$ перспективи розвитку підприємництвва : зб. наук. пр. Харк. нац. автомоб-дор. ун-т. Х. : ХНАДУ. 2019. № 2(23). С. 158-166. 


\section{References}

1. Andrienko, V.M. (2013), Such activities for the security of the bezpeks of Budapest companies [Suchasni pidkhody do zabezpechennia ekonomichnoi bezpeky budivelnykh pidpryiemstv], Building production, No. 55, P. 14-22.

2. Bliznyuk, A. O. (2015), Analysis of the state of the system of management of economic safety of the enterprises of the motor transport industry [Analiz stanu systemy upravlinnia ekonomichnoiu bezpekoiu pidpryiemstv avtotransportnoi haluzi], Problems and prospects of entrepreneurship development, Kharkiv, KhNADU, No 3(10), Vol. 2, P. 121-125.

3. Voronkov, O., Dyachenko, K. S. (2017), Conceptual basis for the study of economic safety of construction enterprises [Kontseptualni zasady doslidzhennia ekonomichnoi bezpeky budivelnykh pidpryiemstv], Bulletin of the Zhytomyr State Technological University, Series: Economic Sciences, No. 4, P. 117-124.

4. Dmitrenko, V. I. (2015), Methodical approach to the assessment of the state of the system of economic security of construction enterprises under the influence of state regulation [Metodychnyi pidkhid do otsiniuvannia stanu systemy ekonomichnoi bezpeky budivelnykh pidpryiemstv pid vplyvom derzhavnoho rehuliuvannia], Bulletin of Cherkasy University, No. 33 (366), Series "Economic Sciences", P. 37-42.

5. Dmytriiev, I., Blyzniuk, A., Onisiforova, V. (2014), Management of economic safety of motor transport enterprise: monograph [Upravlinnia ekonomichnoiu bezpekoiu avtotransportnoho pidpryiemstva: monohrafiia], Kharkiv, $216 \mathrm{p}$.

6. Fisunenko, P. A., Lazhe, M. V. (2015), Features of providing economic safety of construction enterprises [Osoblyvosti zabezpechennia ekonomichnoi bezpeky budivelnykh pidpryiemstv], Ways to increase the efficiency of construction in a market-based relationship, Issue 33, P. 156-164.

7. Cherkasova, S. O. (2013), Forming of organizationally-economic mechanism of process control of strengthening of economic security of industrial enterprises [Formuvannia orhanizatsiino-ekonomichnoho mekhanizmu upravlinnia protsesom zmitsnennia ekonomichnoi bezpeky promyslovykh pidpryiemstv], Economy and realities of time, No. 2, P. 22-27.

8. Dmitriev, I. A., Maiboroda, Yu. V. (2012), Socio-economic essence of small business, problems of its development in Ukraine [Sotsialno-ekonomichna sutnist maloho pidpryiemnytstva, problemy yoho rozvytku v Ukraini], Problems and prospects of entrepreneurship development, No 1, P. 35-38.

9. Onisiforova, V. Yu., Sidelnikova, V. K. (2019), Simplified system of taxation: modern state, advantages, disadvantages and prospects [Sproshchena systema opodatkuvannia: suchasnyi stan, perevahy, nedoliky ta perspektyvy], Problems and prospects of entrepreneurship development, No 2 (23), P. 158-166. 


\section{РЕФЕРАТИ РЕФЕРАТЫ ABSTRACTS}

\section{УДК 658.15; JEL Classification: М 29}

Онісіфорова В.Ю., Сідельнікова В.К. ОПТИМІЗАЦІЯ ОПОДАТКУВАННЯ ЯК ЕФЕКТИВНИЙ ІНСТРУМЕНТ ПІДВИЩЕННЯ РІВНЯ ЕКОНОМІЧНОЇ БЕЗПЕКИ ПІДПРИЕМСТВА

Мета. Дослідження можливості оптимізації оподаткування діяльності підприємства як інструмента підвищення рівня економічної безпеки підприємства. Методика дослідження. В ході дослідження використовувалися методи аналізу і синтезу, метод логічного аналізу. Інформаційними ресурсами дослідження $\epsilon$ електронні інформаційні ресурси і матеріали періодичних видань. Результати. Критерієм вибору системи оподаткування результатів діяльності підприємства $\epsilon$ рівень прибутковості, тобто у разі обрання невідповідної до нього системи, підприємство штучно завищує рівень податків, що спричиняє погіршення показників фінансового стану. Загроза вибору неефективної системи оподаткування діяльності підприємства спрямовує свій вплив на низку складових економічної безпеки підприємства в межах кожного 3 найбільш розповсюджених поглядів на їх класифікацію. Відповідно до системного підходу виокремлюють фінансову складову, що уособлює всі аспекти, які формують фінансовий стан, визначають рівень прибутковості, ліквідність і платоспроможність підприємства. Це головна складова, яка зазнає безпосереднього негативного впливу з боку досліджуваної загрози. Відповідно до ресурсного підходу безпосереднього впливу від завищеного рівня сплачених податків зазнає складова безпеки капіталу, яка стосується безпеки фінансових ресурсів підприємства. Відповідно до ресурсного та функціонального підходів виокремлюється фінансова складова, яка визначається спрямованістю комерційного підприємства на максимізацію прибутку, тобто досліджувана загроза є небезпечною для цієї складової. В умовах класифікації за видом діяльності фінансова безпека формується як безпека фінансового стану, кредитна безпека та безпека фінансових операцій, отже загроза завищених податків $є$ небезпечною в розрізі даної складової. Наукова новизна. Визначено перелік складових економічної безпеки підприємства в межах найбільш поширених підходів до їх виокремлення, що зазнають негативного впливу 3 боку загрози вибору неефективної системи оподаткування результатів діяльності підприємства. Практична значущість. Запропоновані висновки можуть бути використані дослідниками, власниками та керівниками підприємств при визначенні ефективних інструментів управління економічною безпекою підприємства.

Ключові слова: система оподаткування; економічна безпека підприємства; складові економічної безпеки підприємства; ефективність; загроза. 


\section{УДК 658.15; JEL Classification: М 29}

Онисифорова В.Ю., Сидельникова В.К. ОПТИМИЗАЦИЯ НАЛОГООБЛОЖЕНИЯ КАК ЭФФЕКТИВНЫЙ ИНСТРУМЕНТ ПОВЫШЕНИЯ УРОВНЯ ЭКОНОМИЧЕСКОЙ БЕЗОПАСНОСТИ ПРЕДПРИЯТИЯ

Цель. Исследование возможности оптимизации налогообложения деятельности предприятия как инструмента повышения уровня экономической безопасности предприятия. Методика исследования. В ходе исследования использовались методы анализа и синтеза, метод логического анализа. Информационными ресурсами исследования являются электронные информационные ресурсы и материалы периодических изданий. Результаты. Критерием выбора системы налогообложения результатов деятельности предприятия является уровень прибыльности, то есть в случае избрания неподходящей к нему системы, предприятие искусственно завышает уровень налогов, что вызывает ухудшение показателей финансового состояния. Угроза выбора неэффективной системы налогообложения деятельности предприятия влияет на ряд составляющих экономической безопасности предприятия в пределах каждого из наиболее распространенных взглядов на их классификацию. Согласно системного подхода выделяют финансовую составляющую, что олицетворяет все аспекты, которые формируют финансовое состояние, определяют уровень прибыльности, ликвидность и платежеспособность предприятия. Это главная составляющая, которая испытывает непосредственное негативное влияние со стороны исследуемой угрозы. Согласно ресурсного подхода непосредственное воздействие от повышенного уровня уплаченных налогов происходит на составляющую безопасности капитала, которая касается безопасности финансовых ресурсов предприятия. Согласно ресурсному и функциональному подходам выделяется финансовая составляющая, которая определяется направленностью коммерческого предприятия на максимизацию прибыли, то есть исследуемая угроза опасна для этой составляющей. В условиях классификации по виду деятельности финансовая безопасность формируется как безопасность финансового состояния, кредитная безопасность и безопасность финансовых операций, следовательно угроза завышенных налогов опасна в разрезе данной составляющей. Научная новизна. Определен перечень составляющих экономической безопасности предприятия в пределах наиболее распространенных подходов к их выделению, которые испытывают негативное влияние со стороны угрозы выбора неэффективной системы налогообложения результатов деятельности предприятия. Практическая значимость. Предложенные выводы могут быть использованы исследователями, владельцами и руководителями предприятий при определении эффективных инструментов управления экономической безопасностью предприятия.

Ключевые слова: система налогообложения; экономическая безопасность предприятия; составляющие экономической безопасности предприятия; эффективность; угроза. 


\section{UDC 658.15; JEL Classification: M 29}

Onisiforova V.Yu., Sidelnikova V.K. OPTIMIZATION OF TAXATION AS AN EFFECTIVE MEASURE TO INCREASE THE ENTERPRISE ECONOMIC SECURITY

Purpose. Investigation of the possibility of tax optimization of the enterprise activity as a tool to increase the level of enterprise economic security. Methodology of research. Analysis and synthesis methods, logical analysis method were used during the study. Research information resources were electronic information resources and periodical material. Results. The criterion for choosing the taxation system of the enterprise activity results is the level of profitability. That is, in the case of choosing an inappropriate system, the enterprise inflates the level of taxes artificially. This causes deterioration of the financial condition. The threat of choosing an inefficient system of enterprise activity taxation directs its influence to a number of components of the enterprise economic security within each of the most common views on their classification. In accordance with the systematic approach they distinguish the financial component, which represents all aspects that shape the financial condition, determine the level of profitability, liquidity and solvency of the enterprise. This is the main component that is directly affected by the threat under study. According to the resource approach the inflated level of paid taxes direct influences on capital security component, which relates to the security of enterprise financial resources. According to the resource and functional approaches the financial component was separated. It is determined by the commercial enterprise orientation to maximize profit. That is, the investigated threat is dangerous for this component. In terms of activity classification financial security is shaped as financial security, credit security, and financial transactions. Therefore, the threat of excessive taxes is dangerous in the context of this component. Originality. It is determined the list of components of the enterprise economic security within the most commonly used approaches to their isolation. Namely they are adversely affected by the threat of choosing an inefficient system of enterprise activity result taxation. Practical value. The findings will be able to use by researchers, business owners, and executives at selection of an effective tax system.

Key words: taxation system; enterprise economic security; components of enterprise economic security; efficiency; threat. 


\section{Відомості про авторів / Сведения об авторах / About the Authors}

Онісіфорова Валентина Юріївна - кандидат економічних наук, доцент, Харківський національний автомобільно-дорожній університет, доцент кафедри економіки i підприємництва, м. Харків, Україна; e-mail: valentinaonisiforova @ gmail.com; ORCID: http://orcid.org/0000-0001-9899-8427. Моб. 099-499-14-28.

Онисифорова Валентина Юрьевна - кандидат экономических наук, доцент, Харьковский национальный автомобильно-дорожный университет, доцент кафедры экономики и предпринимательства, г. Харьков, Украина.

Onisiforova Valentyna - PhD in Economics, Associate Professor, Kharkiv National Automobile and Highway University, Associate Professor of the Department of Economics and Entrepreneurship, Kharkiv, Ukraine.

Сідельнікова Владислава Костянтинівна - кандидат педагогічних наук, доцент, Харківський національний педагогічний університет імені Г.С. Сковороди, доцент кафедри економічної теорії, фінансів і обліку, м. Харків, Україна; e-mail: vladasid09@gmail.com; ORCID: http://orcid.org/00000002-3851-6067. Моб. 067-701-43-43.

Сидельникова Владислава Константиновна - кандидат педагогических наук, доцент, Харьковский национальный педагогический университет имени Г.С. Сковороды, доцент кафедры экономической теории, финансов и учета, г. Харьков, Украина.

Sidelnikova Vladyslava - PhD in Pedagogical Sciences, Associate Professor, Kharkiv National Pedagogical University named after G.S. Skovoroda, Kharkiv, Ukraine. 